\title{
Fibrates Increase Human Apolipoprotein A-II Expression through Activation of the Peroxisome Proliferator-activated Receptor
}

\author{
Ngoc Vu-Dac, Kristina Schoonjans, Vladimir Kosykh, * Jean Dallongeville, Jean-Charles Fruchart, Bart Staels, \\ and Johan Auwerx \\ Laboratoire de Biologie des Régulations chez les Eucaryotes, U.325 INSERM, Département d'Athérosclérose, Institut Pasteur, \\ 59019 Lille, France; and *Cardiology Research Center, Academy of Medical Sciences, 121552 Moscow, Russia
}

\begin{abstract}
In view of the evidence linking plasma high density lipoprotein (HDL)-cholesterol levels to a protective effect against coronary artery disease and the widespread use of fibrates in the treatment of hyperlipidemia, the goal of this study was to analyze the influence of fibrates on the expression of apolipoprotein (apo) A-II, a major protein constituent of HDL. Administration of fenofibrate $(300 \mathrm{mg} / \mathrm{d})$ to $16 \mathrm{pa}-$ tients with coronary artery disease resulted in a marked increase in plasma apo $A-I I$ concentrations $(0.34 \pm 0.11$ to $0.45 \pm 0.17$ grams/liter; $P<0.01)$. This increase in plasma apo A-II was due to a direct effect on hepatic apo A-II production, since fenofibric acid induced apo A-II mRNA levels to 450 and $250 \%$ of control levels in primary cultures of human hepatocytes and in human hepatoblastoma HepG2 cells respectively. The induction in apo A-II mRNA levels was followed by an increase in apo A-II secretion in both cell culture systems. Transient transfection experiments of a reporter construct driven by the human apo A-II gene promoter indicated that fenofibrate induced apo A-II gene expression at the transcriptional level. Furthermore, several other peroxisome proliferators, such as the fibrate, Wy14643, and the fatty acid, eicosatetraynoic acid (ETYA), also induced apo A-II gene transcription. Unilateral deletions and site-directed mutagenesis identified a sequence element located in the J-site of the apo A-II promoter mediating the responsiveness to fibrates and fatty acids. This element contains two imperfect half sites spaced by 1 oligonucleotide similar to a peroxisome proliferator responsive element (PPRE). Cotransfection assays showed that the peroxisome proliferator activated receptor (PPAR) transactivates the apo A-II promoter through this AII-PPRE. Gel retardation assays demonstrated that PPAR binds to the AII-PPRE with an affinity comparable to its binding affinity to the acyl coA oxidase (ACO)-PPRE. In conclusion, in humans fibrates increase plasma apo A-II concentrations by inducing hepatic apo A-II production. Apo A-II expression is regulated at the transcriptional level by fibrates and fatty acids via the interaction of PPAR with the AII-PPRE,
\end{abstract}

Address correspondence to Dr. Johan Auwerx, L.B.R.E., U.325 INSERM, Institut Pasteur, 1, rue du Prof. Calmette, 59019 Lille Cédex, France. Phone: 20-877752; FAX: 20-877360.

Received for publication 31 January 1995 and accepted in revised form 26 April 1995.

J. Clin. Invest.

(C) The American Society for Clinical Investigation, Inc.

0021-9738/95/08/0741/10 \$2.00

Volume 96, August 1995, 741-750 thereby demonstrating the pivotal role of PPAR in controlling human lipoprotein metabolism. (J. Clin. Invest. 1995. 96:741-750.) Key words: gene regulation - hypolipidemic drugs $\cdot$ hyperlipidemia $\cdot$ peroxisome proliferation • nuclear hormone receptors

\section{Introduction}

Apolipoprotein (apo) A-I and apo A-II are the major protein constituents of high density lipoproteins (HDL), the plasma levels of which are inversely correlated with the incidence of coronary artery disease. Apo A-II exists in plasma as a homodimer linked by an intradisulfide bond at residue $6(1)$. The apo A-II protein sequence (1), cDNA sequence (2-5), and genomic structure (5-8) are known and the human gene has been localized on chromosome 1 (9-12). In man and other mammals, such as rats and mice, apo A-II is mainly produced by the liver, and to a much lesser extent, by the intestine $(13,14)$. The transcription of apo A-II requires the synergistic action of factors, binding to a set of elements in the distal and proximal promoter ( sites A to $\mathrm{N})(15-20)$, as well as in the first intron of its gene (21). The association, reported in certain mouse strains, between elevated apo A-II levels and increased HDL size and HDL-cholesterol levels suggest that the plasma concentration of apo A-II might affect HDL structure and function $(22,23)$. Apo A-II may furthermore compete for the binding of HDL to the putative HDL receptor (24). Recent in vivo studies demonstrate that overexpression of mouse apo A-II in transgenic mice enhances the development of atherosclerotic lesions $(25,26)$, whereas overexpression of human apo A-II in human apo A-I transgenic mice leads to a reduced protection against atherosclerosis (27). This in vivo effect is consistent with the in vitro observations of a decreased capacity of apo AII to stimulate cholesterol efflux (28), and lecithin-cholesterol acyltransferase activity (29), and suggests that apo A-II might reduce the protective effects of HDL against atherosclerosis. This hypothesis is further supported by the differential effects on the development of atherosclerosis of the two main lipoprotein (Lp) particles composing HDL, LpA-I, containing only apo A-I, and LpA-I:A-II, containing both apo A-I and A-II. Numerous data suggest that LpA-I plays the crucial role in the protection against atherosclerosis, whereas the LpA-I:A-II is less efficient (30).

Fibrates, frequently used hypolipidemic agents, affect HDL metabolism in man (31-33). These drugs belong to a group of chemicals called peroxisome proliferators, which also contain, besides fibrates, fatty acids, certain herbicides, and phtalate ester plasticizers. In rodents, all these compounds induce peroxisome proliferation (34-37) and hepatomegaly, which may ultimately lead in these animals to hepatocarcinogenesis after prolonged administration $(38,39)$. The peroxisome proliferation caused 
by these agents is, at least in part, the result of a transcriptional induction of enzymes of the $\beta$-oxidation pathway (40-45). Lately, several studies have emphasized the importance of a group of transcription factors, called peroxisome proliferator activated receptors (PPARs), ${ }^{1}$ in mediating this transcriptional activation process (46-54). At present four distinct PPARs have been described $\alpha, \beta, \gamma, \delta(47,54)$. PPARs are members of the superfamily of nuclear hormone receptors, which after ligand activation, regulate the expression of genes containing specific response elements, called peroxisome proliferator response elements (PPREs) in their regulatory sequences (55, 56). Functional PPREs have been characterized in several of the genes encoding enzymes involved in the peroxisomal $\beta$ oxidation pathway, such as acyl-coA oxidase (ACO) and the trifunctional enzyme (55-60), in the cytochrome P450 4A6 gene $(61,62)$, in the 3-hydroxy-3-methylglutaryl-coA synthase gene (63), in the medium-chain acyl-coA dehydrogenase gene (64), and in the aP2 gene (52). Recently, we also identified a functional PPRE in the $5^{\prime}$ upstream regulatory sequences (URS) of the apolipoprotein A-I gene (65).

In previous studies we analyzed the effects of fibrate treatment on apo A-II gene expression in rodents (66). Given the pivotal role of apo A-II in HDL physiology, we initiated more detailed studies to investigate, first, the effects of fibrates on human apo A-II plasma concentrations and expression and, second, to elucidate the molecular mechanisms underlying the regulation of the apo A-II gene by fibrates. In this report, we demonstrate that fibrates increase plasma concentrations and hepatic production of apo A-II in man. Furthermore, we show that this effect is due to the induction of apo A-II gene expression at the transcriptional level in the hepatocyte. Finally, we show that this effect of fibrates is mediated through binding of the nuclear hormone receptor PPAR to a PPRE, localized in the J-site of the 5'URS of the apo A-II gene.

\section{Methods}

Materials. Fenofibric acid was a kind gift of Dr. A. Edgar (Fournier Laboratories, Daix, France), pirixinic acid (Wy-14643) and tetradecylthioacetic acid (TTA) were kind gifts of Dr. Sharon Burns (WyethAyerst, Princeton, NJ) and Dr. Jon Bremer (Oslo University, Oslo, Norway), respectively. 5,8,11,14-eicosatetraynoic acid (ETYA), bezafibrate, ciprofibrate, and $\alpha$-linolenic acid were purchased from Sigma Chemical Co. (St. Louis, MO).

Human subjects and treatments. Patients with angiographically documented coronary artery disease were screened biochemically and hematologically to exclude disorders likely to produce secondary hyperlipidemia (67). Diabetes mellitus, gout, renal, or hepatic disease constituted specific exclusion criteria. 16 male subjects, corresponding to these criteria and aged between 40 and $60 \mathrm{yr}$, were treated for 8 wk with fenofibrate $300 \mathrm{mg}$ daily (Laboratoires Fournier, Daix, France). Fasting blood samples were drawn before and after treatment. Plasma was isolated and apo A-II concentrations were measured.

Lipid measurements and apo A-II and apo E protein determinations. Plasma apo A-II concentrations were determined by a noncompetitive enzyme linked immunosorbent assay (ELISA). Briefly, polystyrene mi-

1. Abbreviations used in this paper: $5^{\prime} \mathrm{URS}, 5^{\prime}$ upstream regulatory sequence; ACO, acyl CoA oxidase; CAT, chloramphenicol acetyl transferase; DR-1, direct repeat spaced by 1 nucleotide; EMSA, electrophoretic mobility shift assay; ETYA, 5,8,11,14-eicosatetraynoic acid; PPAR, peroxisome proliferator activated receptor; PPRE, peroxisome proliferator response element; TTA, tetradecylthioacetic acid. crotiter plates were coated with a mixture of three monoclonal antibodies to human apo A-II (G02, G03, G013). Duplicate plasma samples were diluted 1:10,000 and 1:7,000 with phosphate saline and were added to the wells along with standards and controls. After incubation, apo A-II antibodies conjugated to peroxidase were added. Color development was performed with the addition of substrate ( $o$-phenylenediamine dichloride). The plates were read at $492 \mathrm{~nm}$ on a microtiter plate reader. Human apo A-II in culture medium of primary human hepatocytes or HepG2 cells was measured by ELISA using the same procedure as for plasma. Human apo $E$ in culture medium (diluted 1:5 and 1:10 with phosphate saline) of primary human hepatocytes and HepG2 cells was measured as previously described (68).

Cloning and construction of recombinant plasmids. A 3-Kb HindIII fragment containing the apo A-II gene promoter was cloned from a human placenta genomic DNA library in Charon 4A (a kind gift from Dr. Stehelin). A fragment containing the $-911 /+160$ sequence of the apo A-II promoter was excised by BglI digestion, blunted, HindIII digested and subsequently cloned into the HindIII and blunted $\mathrm{XbaI}$ sites of pBLCAT5 (69). This construct was designated $-911 /+160$ AIICAT. The basal promoter $(16)(-210 /+160)$ was obtained by PCRamplification using $-911 /+160$ AII-CAT as template, a $-210 /-198$ oligo containing a $5^{\prime} \mathrm{XbaI}$ cloning site $\left(5^{\prime}\right.$-gactctagaTGTACCCCCTTA-3') and an internal CAT oligo as primers. The PCR product was digested with XbaI and BamHI and cloned into pBLCAT5 to give -210 / +160AII-CAT. The distal enhancer region, containing footprints N-I $(-911 /-653)(19)$, was prepared by AluI digestion of the $-911 /+160$ HindIII-BamHI fragment and subsequently subcloned upstream of the basal promoter into $-210 /+160$ AII-CAT, which was PstI digested, blunted, and then HindIII digested. The N-J, N-K and N-L $3^{\prime}$ distal enhancer deletion fragments were obtained by PCR amplification using respectively a $-708 /-722$ oligo (with a $5^{\prime}$ PstI cloning site; $5^{\prime}$-ggaagctgcAGAGGCTTCTACCAG-3'), a -735/-751 oligo (with a $5^{\prime} \mathrm{XbaI}$ cloning site; $5^{\prime}$-cgttctagAGGCACCTGGTCATTTG-3'), and a -773/ -803 oligo ( $5^{\prime}$-gatctAGTGATTAGCCAATATTGAGTCAGCAGGGGC-3'). These fragments were digested and subsequently cloned upstream of the basal promoter in $-210 /+160$ AII-CAT using the corresponding restriction sites.

Site-directed mutagenesis of the J-site PPRE was accomplished using the Amersham oligonucleotide-directed in vitro mutagenesis system based on the method of Nakamaye and Eckstein (70) and a mutated $-741 /-711$ oligo (5'-GGTGCCTTCAAGCTTTACTCTGGTAGAAGCC- $3^{\prime}$ ), which was annealed to the single-stranded $-911 /+160$ template cloned into the M13-mp18 phage.

The $\mathrm{J}_{\mathrm{wt}}$ and $\mathrm{J}_{\mathrm{mt}}$ oligonucleotides containing bases -737 to -715 of the apo A-II gene promoter were cloned into the BamHI/BglII sites of pIC20H (71), digested with HindIII and subcloned upstream of the thymidine kinase (TK) promoter in pBLCAT4 (69) to generate $\mathrm{J}_{\mathrm{wt}}$-TKCAT, $\left(\mathrm{J}_{\mathrm{wt}}\right)_{3}$-TKCAT (respectively containing 1 and 3 copies of the $J_{w t}$-site) and $J_{m t}-$ TKCAT (containing one copy of the $J_{m t}$-site).

The following expression vectors were used. A CMV- $\beta$-gal vector, described by MacGregor and Caskey (72), was used as an internal control for transfection efficiency in mammalian cells. The expression vectors pSG5-mPPAR $\alpha$ (a kind gift of Dr. S. Green, Zeneca, UK) (46) and pSG5-haPPAR $\gamma(53)$, used in transfections, have been described elsewhere. The haPPAR $\gamma$ and $\operatorname{mRXR} \alpha$ were used to synthesize the respective proteins $(47,53,73)$.

Cell culture. The human hepatoma cell line, HepG2, was obtained from E.C.A.C.C. (Porton down, Salisbury, U.K.). HepG2 and HeLa cells were maintained in Dulbecco's modified Eagle's minimal essential medium, supplemented with $10 \%$ fetal calf serum at $37^{\circ} \mathrm{C}$ in a humidified atmosphere of $5 \% \mathrm{CO}_{2} / 95 \%$ air. Medium was changed every other day. For experiments, cells were changed to fresh medium containing $10 \%$ calf serum delipoproteinized by ultracentrifugation in $\mathrm{KBr}(1.21$ grams $/ \mathrm{ml}$ ) and subsequently treated with AG-1-X8 resin (BioRad) plus activated charcoal. Stimuli were dissolved in DMSO (fibrates) or ethanol (fatty acids) and added to the medium at the indicated concentrations and periods of time. Control cells received vehicle only. In the case of 
fatty acids, preincubation with medium was carried out for $45 \mathrm{~min}$ at $37^{\circ} \mathrm{C}$.

Human liver specimens were collected from physically healthy multiorgan donors for transplantation at the Moscow Medical Center, who died after severe traumatic brain injury. Permission to use the remaining, not transplanted part of donor liver for scientific research was obtained from the Ministry of Health of the Russian Federation. Hepatocytes were obtained by a two-step collagenase perfusion as previously described (74). Cells were resuspended in minimal essential medium with Earl's salts (GIBCO-BRL, Paisley, UK) supplemented with $10 \%$ FCS, $2 \mathrm{mM}$ L-glutamine, $50 \mathrm{mg} / \mathrm{ml}$ gentamycine, seeded at a density of $1.5 \times 10^{5}$ cells $/ \mathrm{cm}^{2}$ in 60 -mm plastic culture dishes coated with $20 \mathrm{mg}$ rat tail collagen type I (Sigma Chemical Co.) and incubated in a humified atmosphere of $5 \% \mathrm{CO}_{2} / 95 \%$ air at $37^{\circ} \mathrm{C}$. Medium was renewed after a 4-h adhesion period. After $20 \mathrm{~h}$ the medium was discarded and fenofibric acid (in DMSO, final concentration $0.5 \% \mathrm{vol} /$ vol) was added at the indicated concentrations in serum-free medium. No morphological differences in cell adhesion or cell toxicity (determined by the MTT [tetrazolium] colorimetric test)(75) were observed between control and treated hepatocytes.

RNA analysis. RNA from cells was prepared as described by Chomczynski and Sacchi (76). Northern blot hybridizations and quantification of total cellular RNA were performed as described previously (66). Apo A-II mRNA was measured using a human apo A-II cDNA clone (11). A human GAPDH cDNA clone (77) was used as control. Al probes were labeled by random priming (Boehringer Mannheim). Quantitative analysis was performed by scanning densitometry (BioRad GS670 densitometer).

Transient transfections and expression assays. Transfections in HepG2 cells were performed at $50-60 \%$ confluency by the calcium phosphate coprecipitation procedure with a mixture of plasmids which contained in addition to the reporter and expression vector(s), $0.5 \mu \mathrm{g}$ of CMV- $\beta$-gal expression vector as a control for transfection efficiency. All samples were complemented to an equal total amount of DNA. After $4 \mathrm{~h}$ cells were washed with PBS, and incubated for another $16 \mathrm{~h}$ with fenofibric acid, other fibrates or fatty acids in fresh medium containing $5 \%$ calf serum delipoproteinized by ultracentrifugation in $\mathrm{KBr}$ (1.21 grams/ml) and subsequently treated with AG-1-X8 resin (BioRad) plus activated charcoal. CAT activity was determined on cell extracts as described by Gorman et al. (78). Autoradiographs were quantified by liquid scintillation counting and results were normalized for transfection efficiency. Transfection efficiencies were normalized with the $\beta$-galactosidase activity assay (Promega Protocols and Applications Guide, 2nd Edition). Transfection experiments were performed at least three times.

Electrophoretic mobility shift assays (EMSA). To study the AIIPPRE identified in the $5^{\prime}$ regulatory region of the apo A-II gene, a synthetic double-stranded oligonucleotide spanning nucleotides -737 to -715 of the human apo A-II gene 5' URS was used ( $5^{\prime}$-gatCCTTCAACCTTTACCCTGGTAGA-3'), as well as an oligonucleotide containing 2 point mutations into the potential AII-PPRE ( $5^{\prime}$-gatCCTTCAAGCTTTACTCTGGTAGA-3') (AII-PPRE ${ }_{m \mathrm{~m}}$ ). A 30-bp doublestranded oligonucleotide containing the PPRE of the rat ACO gene and spanning from -575 to -548 (5'-GATCCCGAACGTGACCTTTGTCCTGGTCCC-3') was used as a control PPRE.

haPPAR $\gamma(53)$ and $\operatorname{mRXR} \alpha(73)$ proteins were synthesized in vitro using the rabbit reticulocyte lysate system (Promega). Molecular weight and the quality of the in vitro translated proteins were verified by SDSPAGE. $2 \mu \mathrm{l}$ of PPAR and/or RXR were preincubated in a total volume of $20 \mu \mathrm{l}$ for $15 \mathrm{~min}$ on ice with $2.5 \mu \mathrm{g}$ poly (dI:dC) and $1 \mu \mathrm{g}$ herring sperm DNA in TM buffer ( $10 \mathrm{mM}$ Tris- $\mathrm{HCl}, \mathrm{pH} 7.9,40 \mathrm{mM} \mathrm{KCl}, 10 \%$ glycerol, 0,05\% NP-40 and $1 \mathrm{mM}$ DTT). For competition experiments, increasing amounts of cold oligonucleotide ACO-PPRE, AII-PPRE ${ }_{\mathrm{wt}}$,

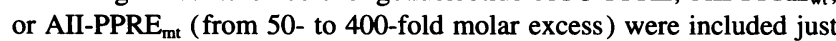
before adding T4-polynucleotide kinase end-labeled oligonucleotide. After $15 \mathrm{~min}$ of incubation at room temperature, DNA-protein complexes were separated by electrophoresis on a $4 \%$ polyacrylamide gel in $0.25 \times \mathrm{TBE}$ buffer at $4^{\circ} \mathrm{C}(79)$.

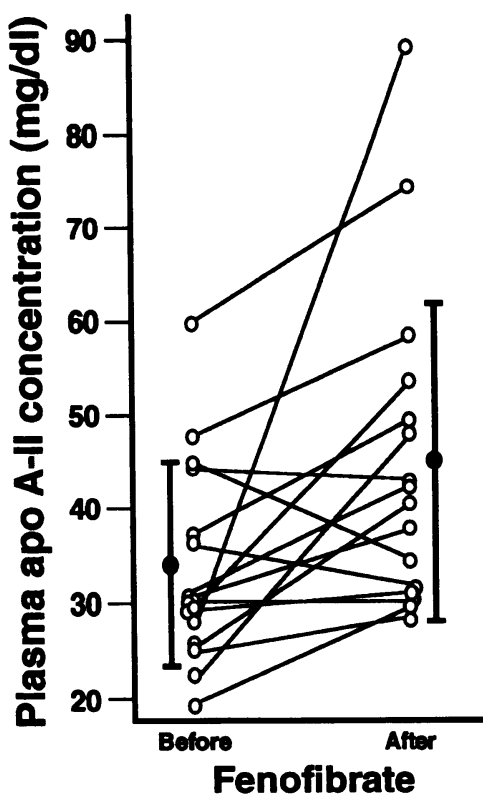

Figure 1. Plasma apo A-II concentrations increase upon treatment with fenofibrate in 16 subjects with coronary artery disease. Plasma was obtained from subjects with angiographically documented coronary artery disease before and after an 8 week treatment with $300 \mathrm{mg} / \mathrm{d}$ of fenofibrate. Apo A-II concentrations were measured as described under materials and methods. The mean \pm SD before and after treatment is indicated by the solid circles $(P<0.01$ by Wilcoxon's test).

Statistical analysis. Data are expressed as the mean \pm SD unless stated otherwise. Student's $t$-, ANOVA, and Wilcoxon tests were used to analyze for statistical significance.

\section{Results}

Plasma apo A-II concentrations increase after fibrate treatment in man. To analyze whether fibrate treatment alters serum apo A-II concentrations in man, 16 subjects with angiographically proven coronary heart disease, were treated with $300 \mathrm{mg}$ of fenofibrate daily for a period of $8 \mathrm{wk}$. Fasting blood was taken immediately before and after completion of the treatment protocol and apo A-II concentrations were measured. Treatment with fenofibrate significantly increased apo A-II concentrations from $0.34 \pm 0.11$ grams $/$ liter to $0.45 \pm 0.17$ grams $/$ liter $(P<0.01$ by Wilcoxon's test) (Fig. 1).

Fibrates increase apo A-II mRNA and protein secretion in primary human hepatocytes and in the human hepatoblastoma cell line HepG2. To study the mechanism of induction of plasma apo A-II concentrations in vivo, the regulation of apo A-II expression by fibrates was studied in two different human cell culture systems. First, the effects of fenofibrate was studied using primary cultures of human hepatocytes. Addition of fenofibric acid for $24 \mathrm{~h}$ to the culture media induced the apo A-II mRNA levels already near-maximally at a dose of $50 \mu \mathrm{M}$ (Fig. $2 \mathrm{~A}$ ). A maximal fivefold stimulation over control was observed at $500 \mu \mathrm{M}$ of fenofibric acid (Fig. $2 A$ ). No change in acyl coA oxidase (ACO) or GAPDH mRNA levels could be observed under these conditions (not shown and Fig. $2 A$ ). The induction of apo A-II mRNA levels was accompanied after 48 $\mathrm{h}$ by a significant increase in apo A-II secretion in the culture medium (Fig. $2 B$ ). In contrast, apo $E$ secretion in the culture medium remained constant under these conditions (Fig. $2 B$ ).

Next, it was investigated whether fenofibric acid also induces apo A-II mRNA levels and protein secretion in the human hepatoblastoma cell line HepG2. When HepG2 cells were treated with $500 \mu \mathrm{M}$ fenofibric acid, apo A-II mRNA levels increased to 154 and $248 \%$ of control values at 24 and $48 \mathrm{~h}$, respectively (Fig. 3, $A$ and $B$ ). To verify whether this induction 


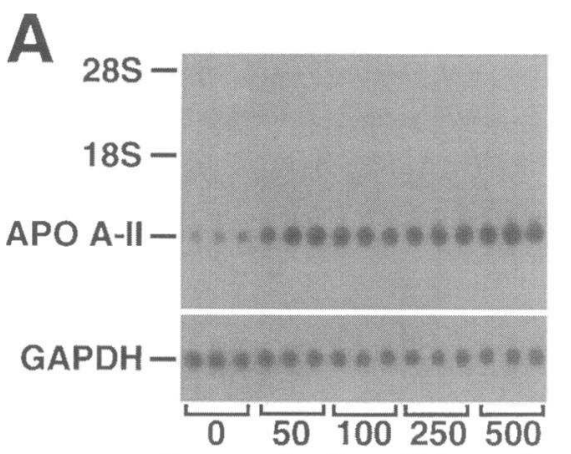

Concentration FF $\left(\times 10^{-6} \mathrm{M}\right)$

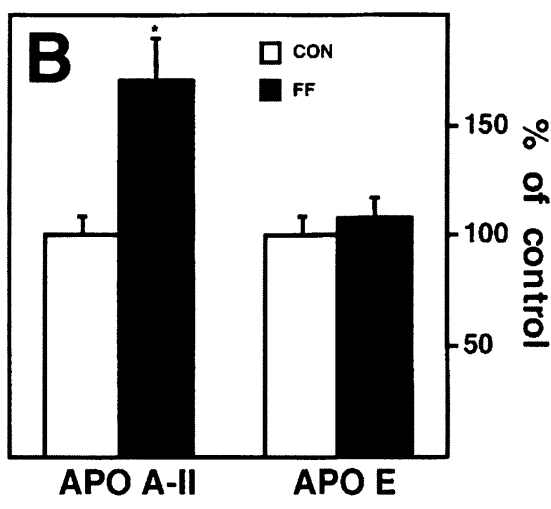

tein concentrations were measured in medium as described in materials and methods. Values are expressed relative to controls and represent the mean $\pm \mathrm{SD}$ of three points. Statistically significant differences ( $t$-test) are indicated by an asterisk.
Figure 2. Fenofibric acid increases apo A-II mRNA levels $(A)$ and protein secretion $(B)$ in primary cultures of adult human hepatocytes. $(A)$ Human hepatocytes were isolated and treated for $24 \mathrm{~h}$ with the indicated doses of fenofibric acid (FF). $5 \mu \mathrm{g}$ of total RNA was subjected to electrophoresis, transferred to a nylon membrane and hybridized to apo A-II (top panel) or GAPDH (bottom panel) cDNA as described in materials and methods. The position of the $18 \mathrm{~S}$ and $28 \mathrm{~S}$ rRNA bands are indicated on the left of the top panel. $(B)$ Human hepatocytes were treated for $48 \mathrm{hr}$ with fenofibric acid (FF, $500 \mu \mathrm{M}$ ) or solvent (CON, DMSO). Apo A-II and apo E pro- in apo A-II mRNA levels was accompanied by increased apo A-II protein secretion, apo A-II concentration was measured in the culture medium of control and fenofibric acid treated cells. Therefore, dose-response experiments were performed in HepG 2 cells and apo A-II secretion was determined after 24 or $48 \mathrm{~h}$ of fenofibric acid (Fig. $3 \mathrm{C}$ ). Apo A-II concentrations in medium already increased significantly after $48 \mathrm{~h}$ at a dose of $100 \mu \mathrm{M}$ fenofibric acid. A further increase was observed at 250 $\mu \mathrm{M}$ both at 24 and $48 \mathrm{~h}$ and maximal effects were attained with $500 \mu \mathrm{M}$ fenofibric acid. At this concentration apo A-II secretion was respectively 3.1- and 3.6-fold higher at 24 and $48 \mathrm{~h}$ of fenofibric acid treatment.

The increase in apo A-II gene expression after fibrates is due to an increase in apo A-II gene transcription. To study whether fibrates induce apo A-II gene expression at the transcriptional level the human apo A-II promoter was cloned in front of the chloramphenicol acetyltransferase (CAT) reporter gene. This construction was transfected in the human hepatoblastoma cell line HepG2 and cells were treated with different doses of fenofibric acid. A viral promoter (Rous sarcoma virus) driven CAT plasmid (RSV-CAT) was transfected as a control. Apo A-II promoter driven CAT activity increased $\sim 1.5$-fold at 250 and $500 \mu \mathrm{M}$ fenofibric acid (Fig. $4 A$ ). The potent fibrate derivative Wy-14643 induced apo A-II promoter activity to $195 \pm 15 \%$ and $180 \pm 18 \%$ at concentrations of 30 and $100 \mu \mathrm{M}$ respectively (Fig. $4 A$ ). By contrast the RSV-driven CAT activity remained unchanged under these conditions (DMSO: $100 \pm 11 \%$; FF $500 \mu \mathrm{M}: 93 \pm 13 \%$ ). These results clearly indicate that the increase in apo A-II production in human liver after fibrates occurs at the transcriptional level.

To investigate whether the increased expression of the apo A-II promoter after fenofibrate was a particular feature of fibrates or a more general effect of peroxisome proliferators and fatty acids, the effects of different peroxisome proliferators on apo A-II gene transcription were analyzed after transient transfection of the $-911 /+160 \mathrm{~A}-\mathrm{II}-\mathrm{CAT}$ construct (Fig. 5). When different fibrates were compared, the expression of the apo A-II promoter was induced by fenofibrate $(1.5$-fold $)$ and by the potent PPAR activator, Wy-14643 (1.8-fold) (80). The sulfurcontaining fatty acid analogue tetradecylthioacetic acid (TTA) did not affect apo A-II promoter activity, whereas the arachidonic acid derivative 5,8,11,14-eicotetraynoic acid (ETYA) provoked a strong increase of apo A-II promoter transcription (twofold). The nonmodified fatty acid, $\alpha$-linolenic acid did not
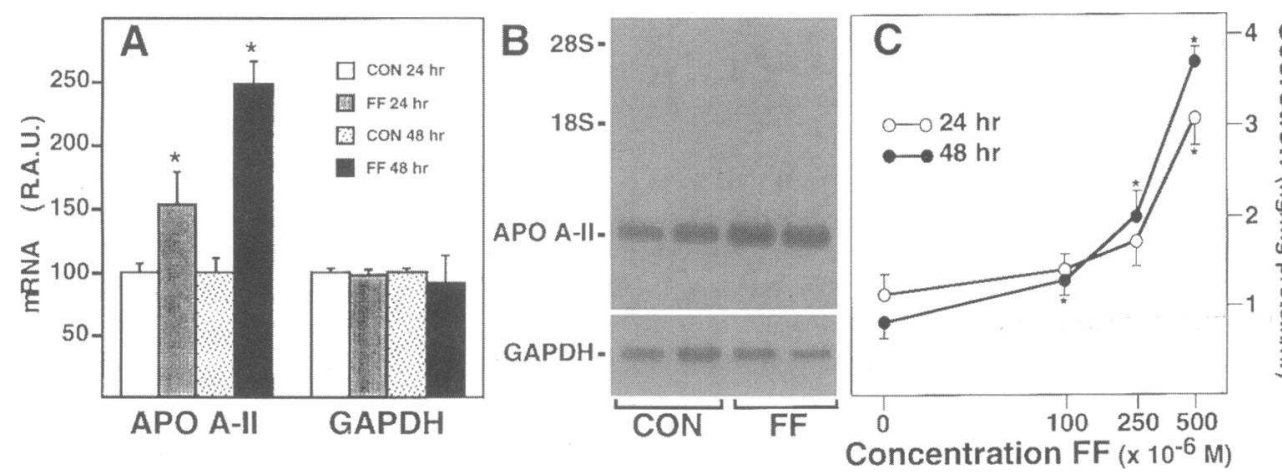

Figure 3. Fenofibric acid induces apo A-II mRNA and protein secretion in the human hepatoblastoma cell-line, HepG2. (A) HepG2 cells were treated for 24 or $48 \mathrm{~h}$ with fenofibric acid ( 500 $\mu \mathrm{M}$ ) or solvent (DMSO). Apo A-II and GAPDH mRNA levels were measured as described in materials and methods. Values are expressed relative to solvent treated controls and represent the mean \pm SD of four points. Statistically significant differences ( $t$ test, $P<0.01$ ) are indiçated by

an asterisk. ( $B$ ) Northern blot analysis. $5 \mu \mathrm{g}$ of total RNA isolated from HepG2 cells treated during $48 \mathrm{~h}$ with $500 \mu \mathrm{M}$ fenofibric acid (FF) or vehicle (CON) was subjected to electrophoresis, transferred to a nylon membrane and hybridized to apo A-II (top panel) or GAPDH (bottom panel) cDNA as described in materials and methods. The position of the 18S and 28S rRNA bands are indicated on the left of the top panel. (C) HepG2 cells were treated for 24 (open circles) or $48 \mathrm{~h}$ (closed circles) with fenofibric acid (in DMSO) at the indicated concentrations. Apo A-II measurements were performed as described under materials and methods. Values represent the mean \pm SD of three points per dose. Statistically significant differences from control (ANOVA, $P<0.001$ ) are indicated by an asterisk. 


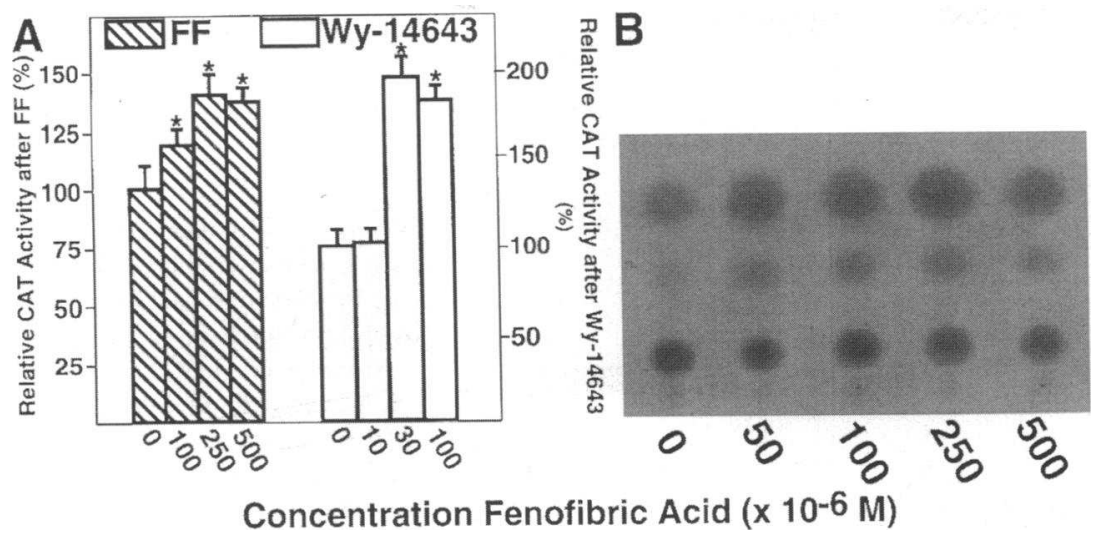

influence apo A-II promoter driven CAT activity. This clearly indicates that the induction of apo A-II promoter activity is not a general effect, but is a property restricted to specific peroxisome proliferators.

Delineation of a PPRE in the regulatory sequences of the apo A-II gene. Next, studies were performed to delineate the cis-acting regulatory sequences within the 5' URS of the apo A-II gene, implicated in the induction of apo A-II gene transcription by peroxisome proliferators, such as fenofibric acid and fatty acids. Since apo A-II promoter activity is largely determined by elements in the distal enhancer (elements I to N) (19), 3' site by site recurrent deletions of the distal enhancer

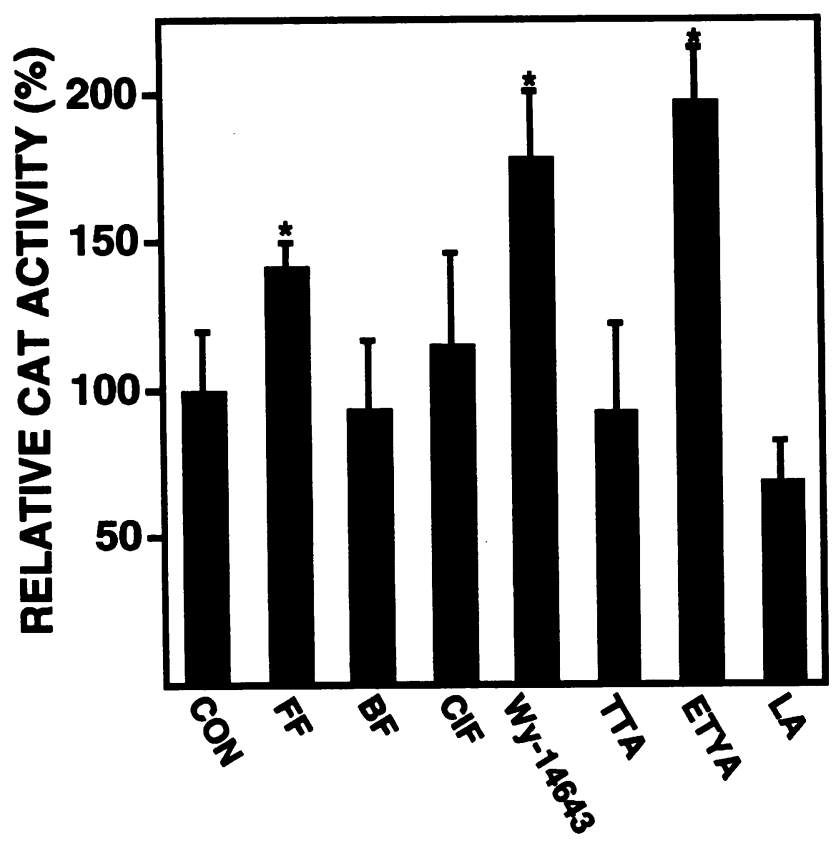

Figure 5. Influence of different fibrates and fatty acids on apo A-II promoter transcription. Hep-G2 cells were transiently transfected with the $-911 /+160$ AII-CAT plasmid and subsequently treated with fenofibric acid (FF; $500 \mu \mathrm{M}$ ), bezafibrate (BF; $500 \mu \mathrm{M}$ ), ciprofibrate (CIF; $500 \mu \mathrm{M}), \mathrm{Wy}-14643(100 \mu \mathrm{M})$, tetradecylthioacetic acid (TTA; 80 $\mu \mathrm{M}), 5,8,11,14$-eicosatetraynoic acid (ETYA; $80 \mu \mathrm{M}$ ), $\alpha$-linolenic acid (LA; $100 \mu \mathrm{M}$ ) or vehicle. CAT activity was measured and expressed (mean $\pm \mathrm{SD})$ as described in materials and methods. Statistically significant differences from controls (ANOVA, $P<0.001$ ) are observed between values followed by different letters.
Figure 4. Fenofibric acid and Wy-14643 induce apo A-II gene expression at the transcriptional level via the apo A-II promoter. $(A)$ HepG2 cells were transiently transfected with $-911 /+160$ AII-CAT plasmid and treated for $16 \mathrm{~h}$ with the indicated doses of fenofibric acid (FF) or Wy-14643 dissolved in DMSO. CAT-activity was measured and expressed (mean $\pm \mathrm{SD}$ ) as described under materials and methods. Statistically significant differences from controls (ANOVA, $P<0.05$ ) are indicated by an asterisk. $(B)$ Representative CAT assay showing the dose-dependent effects of fenofibric acid on apo A-II promoter activity. region were cloned in front of the basal apo A-II promoter and their regulation by fenofibrate was compared with the entire apo A-II regulatory region contained in $-911 /+160$ AII-CAT after transfection in HepG2 cells (Fig. 6). Fenofibric acid treatment induced the CAT activity of the construct containing the entire regulatory region $(-911 /+160)$, as well as constructs containing sites N-I and N-J. However, upon deletion of site $\mathrm{J}$ (plasmids containing only sites $\mathrm{N}-\mathrm{K}$ and $\mathrm{N}-\mathrm{L}$ ) the induction of CAT activity by fenofibric acid was completely abolished. Similarly, cotransfection of the pSG5-mPPAR $\alpha$ expression vector only activated the constructs containing the J-site, which are capable of responding to fenofibric acid (Fig. 6). Addition of fenofibric acid to cells cotransfected with pSG5-mPPAR $\alpha$ and the entire promoter construct $(-911 /+160$ AII-CAT $)$ did not result in a further stimulation relative to cotransfection of pSG5mPPAR $\alpha$ by itself. However, additive effects of fenofibric acid and PPAR were evident for the constructs containing sites N-J and N-I in front of the basal apo A-II promoter. These data suggest the presence of a potential PPRE in the J-site, a regulatory element located between -734 and -716 bp from the transcription start site of the human apo A-II gene, which has previously been shown to bind liver nuclear proteins by footprint assay.

Interestingly, the J-site contains two imperfect copies of a motif related to the consensus steroid hormone receptor binding half-site TGACCT arranged as direct repeats with 1 nucleotide spacing (DR-1). To investigate whether this DR-1 located in the J-site represents the functional response element mediating the observed effects of PPAR on apo A-II gene transcription, the DR-1 site was mutated (Fig. $7 A$ ) and its activity was compared to the activity of the wild-type (wt) construct ( -911 / +160 AII-CAT) transfected in HepG2 cells (Fig. 7, $B$ and $D$ ). Mutation of the J-site DR-1 sequence not only resulted in a loss of inducibility of apo A-II promoter regulation by PPAR and fenofibric acid, but also in a strong decrease in baseline level CAT activity (Fig. $7 \mathrm{D}$ ). This decrease in basal CAT activity suggests that the J-site not only mediates the transcriptional response to PPAR and peroxisome proliferators, but also is a strong site driving the basal expression of the apo A-II promoter.

To prove that the $\mathrm{J}$ site could function as a PPRE in front of a heterologous promoter, the $\mathrm{J}_{\mathrm{wt}}$ site was cloned as a monoand trimer in front of the heterologous thymidine kinase (TK) promoter to generate the construct $\mathrm{J}_{\mathrm{wt}}-T K-C A T$ ( Fig. 7 A). Upon cotransfection of these constructs with mPPAR $\alpha$ into HepG2 cells it was evident that the $\mathrm{J}$ site could transmit PPAR activation to this heterologous promoter (Fig. $7 \mathrm{C}$ ). The TK-CAT 


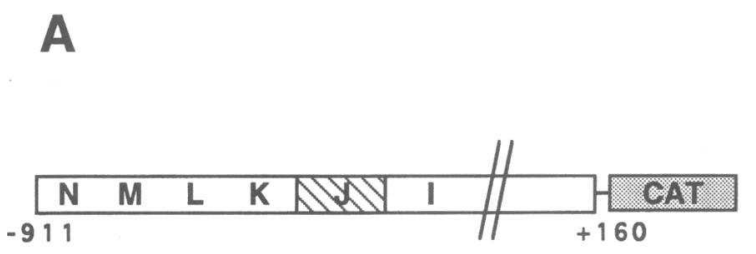

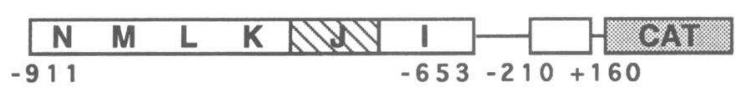

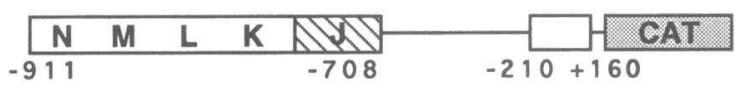
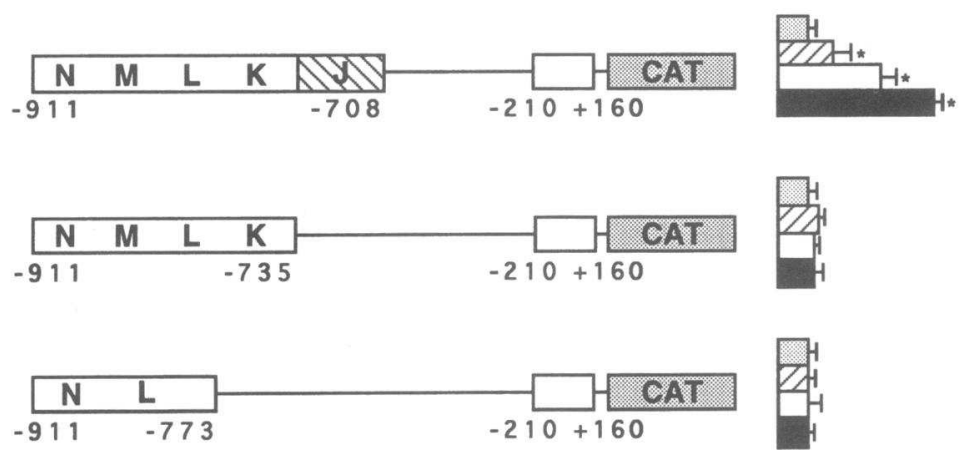
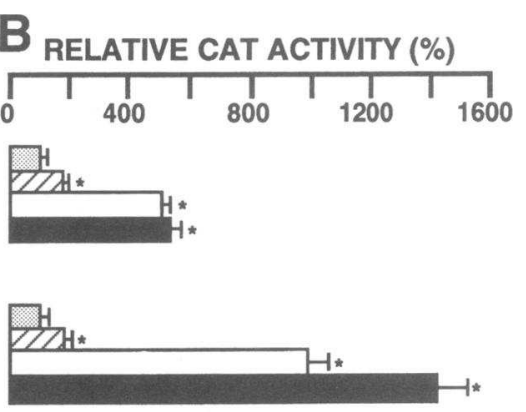

Figure 6. The induction of apo A-II gene transcription by fibrates and PPAR is mediated by the apo A-II promoter $\mathbf{J}$ site in the apo A-II promoter. HepG2 cells were transfected with different apo A-II gene promoter deletion constructs, schematically depicted in $A$, in the presence of cotransfected mPPAR $\alpha$ or pSG5 vector plasmid. Cells were treated with fenofibric acid $(500 \mu \mathrm{M})$ or vehicle (DMSO) and CAT activity was measured and expressed (mean $\pm \mathrm{SD}$ ) as described in Methods. Values statistically different from vehicle treated, pSG5 cotransfected apo A-II promoter constructs are indicated by an asterisk. vector or the $\mathrm{J}_{\mathrm{mt}}$-TK-CAT were only marginally activated by mPPAR $\alpha$ (Fig. 7 C). However, in HepG2 cells PPAR displays a substantial transactivation potential even in the absence of exogenously added activators (see Figs. $6 B$ and $7 B$ ). Therefore, to determine whether PPAR mediates the activation of apo A-II gene transcription by fibrates, HeLa cells were transfected with the $\left(\mathrm{J}_{\mathrm{wt}}\right)_{3}$-TK-CAT construct in the presence or not of cotransfected PPAR and the influence of fenofibrate or Wy14643 treatment was analyzed next (Fig. 8). Addition of fenofibrate or Wy-14643 alone did not activate $\left(\mathrm{J}_{\mathrm{wt}}\right)_{3}$-TK-CAT expression in HeLa cells. Cotransfection of PPAR resulted in a nearly twofold activation and treatment with fenofibrate and Wy-14643 resulted in a substantial further increase in CAT activity (3- and 8-fold, respectively) (Fig. 8). In contrast, fibrate treatment, whether in the presence of cotransfected mPPAR $\alpha$ or not, did not activate $\mathrm{J}_{\mathrm{mt}}$-TK-CAT expression in HeLa cells (data not shown). Taken together, these data strongly argue that the $\mathrm{J}$ site of the apo A-II gene contains a bona-fide PPRE (AII-PPRE), which mediates the fenofibrate induction of apo A-II gene transcription through PPAR activation.

$P P A R / R X R$ heterodimers bind to the AII-PPRE in the $J$ site of the apo A-II gene. Next, it was investigated whether PPAR could bind to the AII-PPRE by electrophoretic mobility shift assays (EMSA). Incubation of a double-stranded oligonucleotide corresponding to the $\mathrm{J}$ site $\left(\mathrm{J}_{\mathrm{wt}}\right)$ and spanning sequences from -737 to -715 relative to the transcription initiation site of the apo A-II gene with in vitro produced haPPAR $\gamma$ and $\operatorname{mRXR} \alpha$ resulted in the formation of a retarded complex (Fig. 9). Similar binding data were obtained when XPPAR $\alpha$ was used instead of haPPAR $\gamma$, and $\operatorname{mRXR} \alpha$ was replaced by $\operatorname{mRXR} \beta$ (data not shown), demonstrating that the AII-PPRE was capable of binding different PPAR/RXR heterodimers. By contrast, haPPAR $\gamma$ homodimers were incapable of binding to the $\mathrm{J}_{\mathrm{wt}}$ site (Fig. 9, lane 4). On a labeled double-stranded oligonucleotide containing the mutated AII-PPRE (AII-PPRE $\mathrm{mt}_{\mathrm{mt}}$ ) no binding of
haPPAR $\gamma$ and $\operatorname{mRXR} \alpha$ heterodimers was observed, thereby confirming and extending the results of our transfection experiments (Fig. 9, lane 8).

To demonstrate that the proteins binding to the AII-PPRE were identical to those binding to the classical ACO-PPRE, cross competition experiments were performed next. In a first experiment, it was tested whether cold ACO-, AII-PPRE $\mathrm{wt}_{\mathrm{w}}$ - and AII-PPRE $\mathrm{mt}^{-}$oligonucleotides could compete with the binding of haPPAR $\gamma / \mathrm{mRXR} \beta$ heterodimers to the labeled AII $_{\mathrm{wt}}$ PPRE oligonucleotide (Fig. 9 lanes 11-22). Both the ACO and AIIPPRE $_{\mathrm{wt}}$ sequences competed, whereas the AII-PPRE $\mathrm{mt}_{\mathrm{mt}}$ did not compete with the binding of haPPAR $\gamma / \mathrm{mRXR} \alpha$ heterodimers to the AII-PPRE $\mathrm{wt}_{\mathrm{wt}}$. Interestingly, the competition was as efficient with the cold ACO-PPRE and AII-PPRE ${ }_{\mathrm{wt}}$ oligonucleotides, suggesting that the AII-PPRE is a strong PPRE. In a second experiment, cross competition was performed using ACO-PPRE as a probe (data not shown). Also in this experiment equivalent molar ratios of cold ACO or AII-PPRE $\mathrm{wt}_{\mathrm{wt}}$ oligonucleotide could prevent haPPAR $\gamma / \mathrm{mRXR} \alpha$ heterodimers from binding to the ACO-PPRE. In contrast, cold AII-PPRE ${ }_{\mathrm{mt}}$ oligonucleotide could not compete for the binding of haPPAR $\gamma /$ $\mathrm{mRXR} \alpha$ heterodimers from binding to the ACO-PPRE.

\section{Discussion}

In view of the evidence linking elevated levels of HDL-cholesterol to a protective effect against the development of coronary artery disease and the widespread use of fibrates in the treatment of diet-resistant hyperlipidemia, one of the goals of our research was to determine whether fibrates regulate the expression of apo A-II, one of the major protein constituents of HDL, and to understand the molecular mechanisms underlying its regulation. Despite the beneficial effects of these drugs on apo B-containing lipoproteins, results from most of the clinical studies indicate that fibrates favor the occurrence of a HDL profile consisting of an augmentation of LpA-I/A-II particles, which are less 


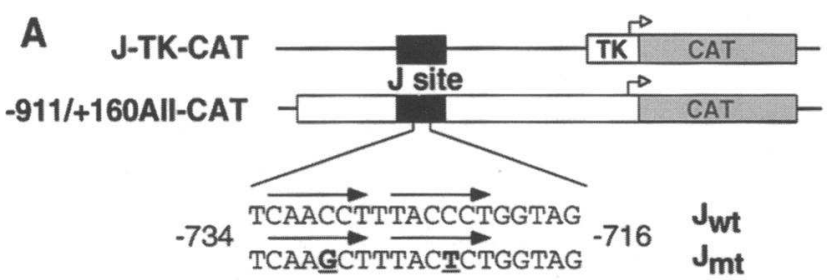

B
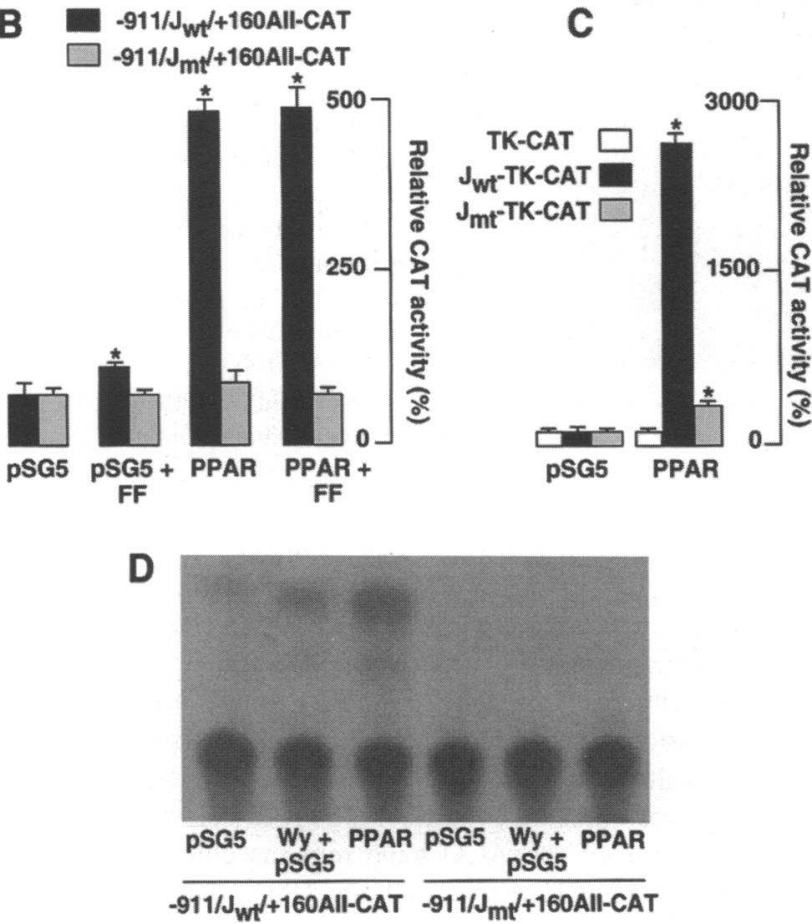

Figure 7. The $\mathrm{J}$ site in the apo A-II promoter contains a functional PPRE: effects of point mutation in the $J$ site and effects of the $J$ site on a heterologous promoter. $(A)$ Schematic representation of the constructs J-TK-CAT and $-911 /+160$ AII-CAT. The wild type as well as the mutated apo A-II $J$-sites are indicated ( $\mathrm{J}_{\mathrm{wt}}$ and $\mathrm{J}_{\mathrm{mt}}$, respectively). B. Effects of fenofibric acid and PPAR on the expression of apo A-II promoter containing a wild-type $\left(-911 / \mathrm{J}_{\mathrm{w}} /+160\right.$ AII-CAT $)$ or mutant $\left(-911 / \mathrm{J}_{\mathrm{mt}} /+160\right.$ AII-CAT) AII PPRE. HepG2 cells were transfected with the indicated plasmids in the presence of cotransfected mPPAR $\alpha$ or pSG5 vector plasmids. Cells were treated with fenofibric acid ( 500 $\mu \mathrm{M}$ ) or vehicle (DMSO) and CAT activity was measured and expressed as described under materials and methods. Statistically significant differences from control (pSG5) are indicated by an asterisk. $(C)$ PPAR activates the wild-type $\left(J_{\mathrm{wt}}\right)$, but not the mutant $\left(\mathrm{J}_{\mathrm{mt}}\right) \mathrm{J}$-site when cloned upstream of the heterologous thymidine kinase promoter (TK) promoter. HepG2 cells were transfected in the presence of cotransfected mPPAR $\alpha$ or pSG5 vector plasmids. Cells were treated with fenofibric acid ( 500 $\mu \mathrm{M})$ or vehicle and CAT activity was measured and expressed as described under materials and methods. Statistically significant differences from control (pSG5 cotransfected constructs) are indicated by an asterisk. (D) CAT assay demonstrating the effects of Wy-14643 (30 $\mu \mathrm{M})$ or cotransfection of mPPAR $\alpha$ on the $-911 / \mathrm{J}_{\mathrm{wl}} /+160 \mathrm{AII}-\mathrm{CAT}$ and $-911 / \mathrm{J}_{\mathrm{mt}} /+160$-CAT vectors.

efficient cholesterol acceptors than LpA-I particles (31). Interestingly, the clinical data in this paper demonstrate that the change towards an altered HDL profile after fibrate treatment, is associated with a marked increase in apo A-II plasma concentrations. Furthermore, we demonstrate that the increase in apo
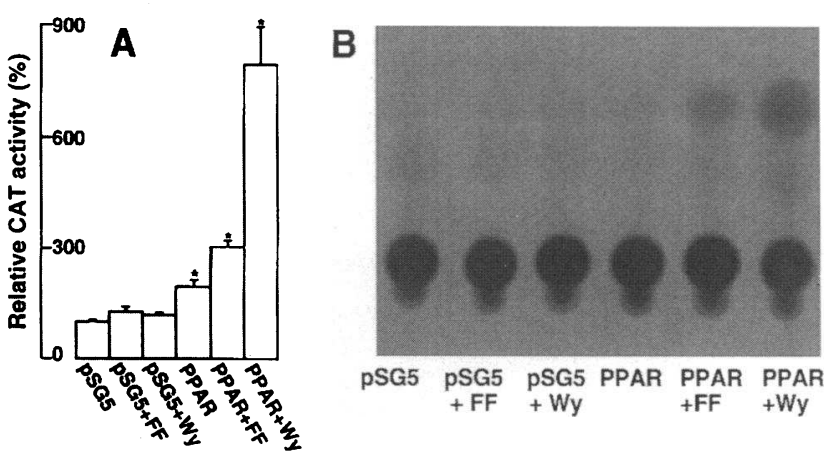

Figure 8. PPAR expression is required for activation of the apo A-II Jsite by fibrates. $(A)$ HeLa cells were transfected with the $\left(\mathrm{J}_{\mathrm{w}}\right)_{3}$ TKCAT plasmid in the presence of cotransfected mPPAR $\alpha$ or PSG5 vector plasmids. Cells were treated with fenofibric acid (FF; $250 \mu \mathrm{M}$ ), Wy-14643 (Wy; $100 \mu \mathrm{M}$ ) or vehicle (DMSO) and CAT activity was measured and expressed as described under materials and methods. Statistically significant differences from control (pSG5) are indicated by an asterisk. $(B)$ CAT assay demonstrating the effects of cotransfection of mPPAR $\alpha$ and treatment with fenofibric acid (FF; $250 \mu \mathrm{M}$ ) and Wy-14643 (Wy; $100 \mu \mathrm{M})$ on $\left(\mathrm{J}_{\mathrm{w}}\right)_{3}$ TKCAT expression in HeLa cells.

A-II protein concentration after fenofibrate is caused by a direct effect of fibrates on hepatic apo A-II production, and is therefore not merely a consequence of alterations in plasma lipid concentrations. In fact, treatment of primary human hepatocytes or HepG2 cells with fenofibric acid, the active form of fenofibrate, results in a corresponding increase in apo A-II gene expression and protein production. This increase in apo A-II mRNA steady state levels suggested that regulatory sequences in the apo A-II gene are functionally implicated in this induction. Results from transfection experiments showed that fenofibrate has an overall positive effect on the activity of the apo A-II promoter. Recently, it has been shown that a group of transcription factors, termed PPARs, belonging to the nuclear hormone receptor gene superfamily $(46,47)$, mediate the effects of peroxisome proliferators, such as fibrates and various fatty acids, on gene expression $(47,48)$. Consistent with this hypothesis, we demonstrated, by cotransfection of a PPAR expression vector, that PPAR mediates the fenofibric acid-dependent transcriptional activation of the apo A-II gene. It is noteworthy that the apo A-II promoter is also transcriptionally activated by PPAR in the absence of fenofibric acid or other exogeneous stimuli. This could be due to the inherent activity of the transcriptional activating functions of PPAR (81) or, alternatively and perhaps more likely, to the presence of (a) natural ligand $(s)$, constitutively activating PPAR in these cells. It can, however, not be excluded that both mechanisms act together, since fibrates could potentiate the positive effect of PPAR on the truncated apo A-II promoter constructs. By using unilateral 3' deletions of the apo A-II distal enhancer region, we localized the responsive region in the $\mathrm{J}$ site (19). This site was found to contain two imperfect copies of a motif related to the consensus steroid hormone receptor half-site TGACCT arranged with a spacing of 1 nucleotide (or DR-1). Previous studies have shown that this J element forms two DNA-protein complexes in hepatocyte nuclear extracts, termed AIIJ1 and AIIJ2, the last of which has some similarities with NF-BA-1 $(82,83)$. Furthermore, several orphan nuclear receptors, such as HNF-4, EAR2, EAR3, and ARP-1, have been shown to interact with this $\mathrm{J}$ site $(20,82)$. In fact, HNF-4 

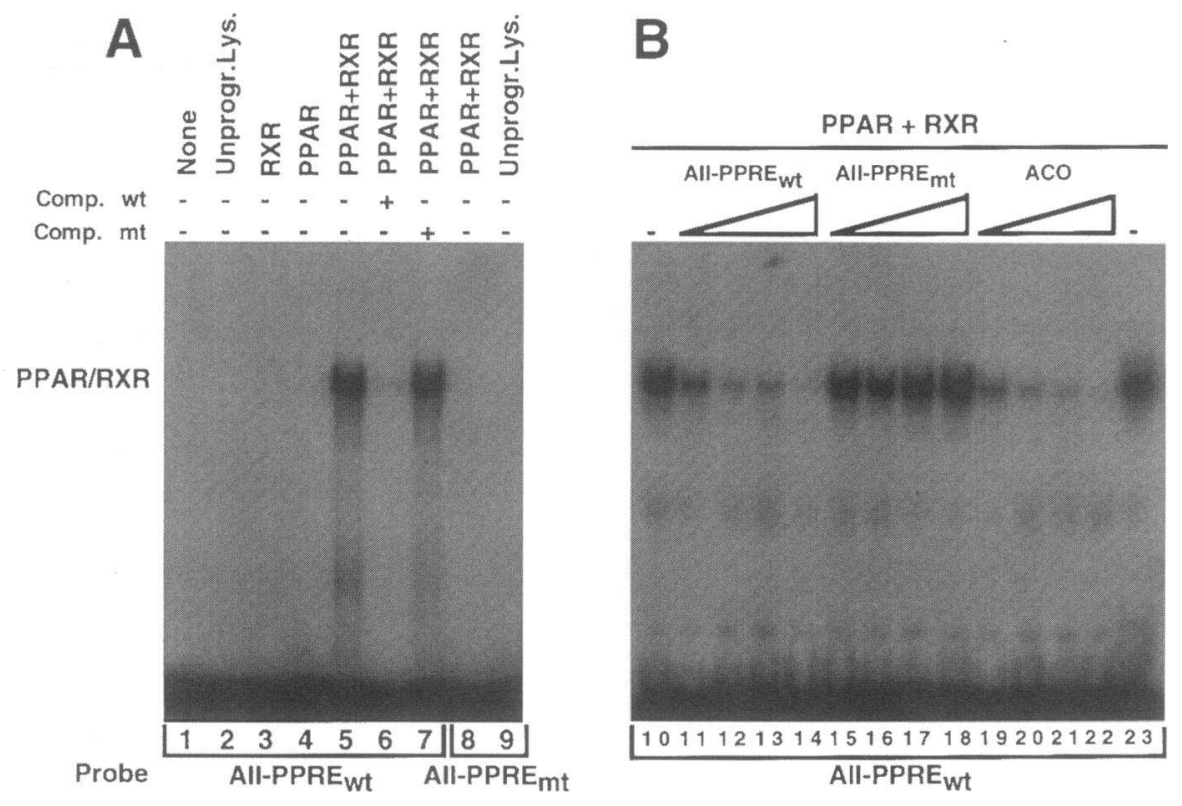

Figure 9. PPAR/RXR heterodimers bind to the J-site wild-type (AII-PPRE $\mathrm{wt}_{\mathrm{wt}}$ ), but not to the mutated AII-PPRE (AII-PPRE ${ }_{\mathrm{mt}}$ ). $(A)$ Gel retardation assays were performed on end-labeled AII-PPRE ${ }_{\mathrm{wt}}$ or AII-PPRE $\mathrm{mt}_{\mathrm{mt}}$ oligonucleotides in the presence of in vitro transcribed/translated haPPAR $\gamma$ (PPAR), $\mathrm{mRXR} \alpha(R X R)$ or unprogrammed reticulocyte lysate as described under materials and methods in the presence $(+)$ or not $(-)$ of 100 -fold molar excess of unlabeled wild-type (comp wt) or mutant (comp mt) oligonucleotide (none $=$ no extract added). $(B)$ Competition experiments for binding to in vitro transcribed/translated haPPAR $\gamma / \mathrm{mRXR} \alpha$ were performed using end-labeled AII$\mathrm{PPRE}_{\mathrm{w}}$ oligonucleotide in the absence (-) or presence of 50,100, 200 and 400-fold molar excess of cold AII-PPRE ${ }_{\mathrm{wt}}$, AII$\mathrm{PPRE}_{\mathrm{mt}}$ or ACO oligonucleotide.

induces, whereas EAR-2, EAR-3, and ARP-1 reduce apo A-II gene transcription upon binding to this element (20). In view of the binding of multiple nuclear hormone receptors to this $\mathrm{J}$ element, it was no surprise that PPAR could also interact with this element. Indeed, site-directed mutagenesis experiments demonstrated that this DR-1 motif mediates the effects of PPAR and fibrates on apo A-II gene expression, whereas EMSA experiments indicated that PPAR/RXR heterodimers bind to the AIIPPRE. Moreover, cross-competition experiments indicated that

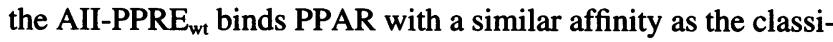
cal ACO-PPRE. These data hence implicate unequivocally PPAR in the response of the apo A-II gene to fibrate hypolipidemic drugs. In view of the proposed role of PPARs in mediating the effects of nutrition on gene expression it is tempting to speculate that nutritional effects on apo A-II gene expression also might be mediated via transcription factors belonging to the PPAR family. The induction of apo A-II promoter activity by certain fatty acid derivatives is an argument in support of this hypothesis. More detailed experiments to study the effects of various nutritional compounds on apo A-II expression are currently undertaken in our laboratory.

In contrast to the increase in apo A-II mRNA levels in human hepatocytes and hepatoma cells, hepatic apo A-II mRNA levels decrease after in vivo administration of fibrates to rodents (66). However, in rat liver the decrease in apo A-II mRNA levels was not associated with altered transcription activity of the apo A-II gene, whereas in human liver increased apo A-II mRNA levels are linked to PPAR-mediated induction of apo A-II gene transcription. The different mechanisms involved in this species-specific opposite regulation of apo A-II mRNA levels are unclear at present, but several possible hypothesis can be forwarded. First, differences may exist between species in either the cis-acting elements, involved in these regulatory processes, or in the general promoter structure, leading to the absence of transcriptional regulation in rats, but not in humans. Second, qualitative and/or quantitative differences in trans-acting factors present in rodent or human liver may contribute to species-specific responses to certain agents. This is, however, less likely to explain the differential response to fibrates. In fact, it is clearly established that both rat and man produce multiple PPARs, the transcription factors involved in mediating the genomic response to peroxisome proliferators. Finally, species-specific metabolic differences could also affect the response to fibrates. In rodents these compounds act by inducing the expression of several genes coding for peroxisomal enzymes which results in a strong proliferation of peroxisomes and an extreme hepatomegaly $(40,41,44,84)$. In contrast to rodents, the expression of the ACO gene remains constant in human hepatocytes treated with fenofibrate (85), thereby indicating that fibrates have no or only a very limited capacity to induce peroxisomal enzymes in humans, as has been suggested previously by several authors (34-37). Since it is hypothesized that, at the cellular level, fibrates act indirectly probably by affecting intermediary steps of intracellular lipid metabolism (34), it is conceivable that species-specific differences in intracellular metabolic responses to fibrates may differently affect gene expression via transcriptional or post-transcriptional regulatory mechanisms.

From these data, as well as from previous studies from our and other laboratories, it becomes increasingly evident that PPARs not only play an important role in the control of intracellular lipid metabolism and $\beta$-oxidation, but also have a wide impact on lipid transport and lipoprotein physiology. When one considers HDL metabolism, it is evident that PPAR not only controls expression of apo A-II, but also the production rate of apo A-I, the other major protein component of HDL. In previous studies, we have indeed shown that PPAR and its activators have also a complex effect on the expression of apo A-I. On the one hand, fibrates exert a negative and probably PPARindependent effect on apo A-I gene transcription mediated by sequence elements located in the apo A-I basal promoter. On the other hand, this effect is counteracted by a PPAR-dependent positive effect mediated by a PPRE located in the A-site of the apo A-I promoter (65). In man this delicate interplay of regulation through the PPAR binding A site and the apo A-I basal promoter can result in a variable regulation of the entire apo A-I promoter depending upon the cellular context. Fibrates and PPAR not only have major effects on the metabolism of HDL 
particles, but they also affect the metabolic fate of apo B containing particles. In fact, we showed that fibrates diminish hepatic production of apo C-III, a mechanism which may lie at the basis of the hypotriglyceridemic action of these compounds (85). Indeed, due to the reduced apo C-III concentration, both LPL-mediated lipolysis as well as, receptor-mediated clearance of triglyceride-rich particles will be improved, resulting in lowering of plasma triglyceride concentrations.

In conclusion, the results from these studies show that in humans apo A-II plasma concentrations increase upon treatment with fibrates, as a result of a PPAR-mediated induction of apo A-II gene transcription leading to an increase in hepatic apo AII production. The regulation of the apo A-II gene by fibrates is another example indicating that, unlike in rodents, fibrates/ PPAR can modulate gene expression in humans without the concurrent induction of peroxisomal enzymes.

\section{Acknowledgments}

E. Baugé, D. Cayet, and R. Saladin are thanked for excellent technical help and Prof. J. Shepherd for providing serum samples of the clinical study.

This work was supported by CNRS, INSERM, and by grants of the "Fondation pour la Recherche Medicale."

\section{References}

1. Brewer, H. B., S. E. Lux, R. Ronan, and K. M. John. 1972. Amino acid sequence of human apoLp-GlnII (apo A-II), an apolipoprotein isolated from the high density lipoprotein complex. Proc. Natl. Acad. Sci. USA. 69:1304-1308.

2. Knott, T. J., L. M. Priestley, M. Urdea, and J. Scott. 1984. Isolation and characterization of a cDNA encoding the precursor for human apolipoprotein A-II. Biochem. Biophys. Res. Commun. 120:734-740.

3. Lackner, K. J., S. W. Law, and H. B. Brewer. 1984. Human apolipoprotein A-II: complete nucleic acid sequence of preproapoA-II. FEBS (Fed. Eur. Biochem. Soc.) Lett. 175:159-164

4. Sharpe, C. R., A. Sidoli, C. S. Shelley, M. A. Lucero, C. C. Shoulders, and F. E. Baralle. 1984. Human apolipoproteins A-I, A-II, C-II and C-III. cDNA sequences and mRNA abundance. Nucleic Acids Res. 12:3917-3932.

5. Tsao, Y. K., C. F. Wei, D. L. Robberson, A. M. Gotto, and L. Chan. 1985. Isolation and characterization of the human apolipoprotein A-II gene. J. Biol. Chem. 260:15222-15231.

6. Knott, T. J., S. C. Wallis, M. E. Robertson, L. M. Priestley, M. Urdea, L. B. Rall, and J. Scott. 1985. The human apolipoprotein A-II gene: structural localization and sites of expression. Nucleic Acids Res. 13:6387-6398.

7. Lackner, K. J., S. W. Law, and H. B. Brewer. 1985. The human apolipoprotein A-II gene: complete nucleic acid sequence and genomic organization. Nucleic Acids Res. 13:4597-4608.

8. Shelley, C. S., C. R. Sharpe, F. E. Baralle, and C. C. Shoulders. 1985 Comparison of the human apolipoprotein genes. Apo A-II presents a unique functional intron exon junction. J. Mol. Biol. 186:43-51.

9. Lackner, K. J., S. W. Law, H. B. Brewer, A. Y. Sakaguchi, and S. L. Naylor. 1984. The human apolipoprotein A-II gene is located on chromosome 1. Biochem. Biophys. Res. Commun. 122:877-883.

10. Knott, T. J., R. L. Eddy, M. E. Robertson, L. M. Priestley, J. Scott, and T. B. Shows. 1984. Chromosomal localization of the human apoprotein C-I and of a polymorphic apoprotein A-II gene. Biochem. Biophys. Res. Commun. 125:299-306

11. Moore, M. N., F. T. Kao, Y. K. Tsao, and L. Chan. 1984. Human apolipoprotein A-II: nucleotide sequence of a cloned cDNA, and localization of its structural gene on chromosome 1. Biochem. Biophys. Res. Commun. 123:1-7.

12. Lusis, A. J., B. A. Taylor, R. W. Wangenstein, and R. C. LeBoeuf. 1983 Genetic control of lipid transport in mice: II. Genes controlling structure of high density lipoproteins. J. Biol. Chem. 258:5071-5078.

13. Hussain, M., and V. I. Zannis. 1990. Intracellular modification of human apolipoprotein (apo A-II) and sites of apo A-II synthesis: Comparison of apo A-II with apo C-II and apo C-III isoproteins. Biochemistry. 29:209-217.

14. Schonfeld, G., W. Patsch, L. L. Rudel, C. Nelson, M. Epstein, and R. E. Olson. 1982. Effects of dietary cholesterol and fatty acids on plasma lipoproteins. J. Clin. Invest. 69:1072-1080.

15. Cardot, P., J. Chambaz, C. Cladaras, and V. I. Zannis. 1991. Regulation of the human apo A-II gene by synergistic action of factors binding to the proximal and distal regulatory elements. J. Biol. Chem. 266:24460-24470.

16. Shelley, C. S., and F. E. Baralle. 1987. Dual tissue-specific expression of apo A-II is directed by an upstream enhancer. Nucleic Acids Res. 15:3801-3821.

17. Lucero, M. A., D. Sanchez, A. R. Ochoa, F. Brunel, G. N. Cohen, F. E. Baralle, and M. M. Zakin. 1989. Interaction of DNA-binding proteins with the tissue-specific human apolipoprotein A-II enhancer. Nucleic Acids Res. 17:22832300.

18. Cardot, P., D. Pastier, J. M. Lacorte, M. Mangeney, V. I. Zannis, and J. Chambaz. 1994. Purification and characterization of nuclear factors binding to the negative regulatory element $\mathrm{D}$ of human apolipoprotein A-II promoter: a negative regulatory effect is reversed by GABP, an Ets-related protein. Biochemistry. 33:12139-12148.

19. Chambaz, J., P. Cardot, D. Pastier, V. I. Zannis, and C. Cladaras. 1991. Promoter elements and factors required for hepatic transcription of the human Apo A-II gene. J. Biol. Chem. 266:11676-11685.

20. Ladias, J. A. A., M. Hadzopoulou-Cladaras, D. Kardassis, P. Cardot, J. Cheng, V. Zannis, and C. Cladaras. 1992. Transcriptional regulation of human apolipoprotein genes apoB, apoCIII, and apoAII by members of the steroid hormone receptor superfamily HNF-4, ARP-1, EAR-2, and EAR-3. J. Biol. Chem. 267:15849-15860

21. Bossu, J. P., F. L. Chartier, N. Vu-Dac, J. C. Fruchart, and B. Laine. 1994. Transcription of the human apolipoprotein A-II is down-regulated by the first intron of its gene. Biochem. Biophys. Res. Commun. 202:822-829.

22. Mehrabian, M., J.-H. Qiao, R. Hyman, D. Ruddle, C. Laughton, and A. J. Lusis. 1993. Influence of the apoA-II gene locus on HDL levels and fatty streak development in mice. Arterioscler. Thromb. 13:1-10.

23. Doolittle, M. H., R. C. LeBoeuf, C. H. Warden, L. M. Bee, and A. J. Lusis. 1990. A polymorphism affecting apolipoprotein A-II translational efficiency determines high density lipoprotein size and composition. J. Biol. Chem. 265:16380-16388.

24. Fidge, N. H., and P. J. Nestel. 1985. Identification of apolipoproteins involved in the interaction of human high density lipoproteins with receptors on cultured cells. J. Biol. Chem. 260:3570-3575.

25. Hedrick, C. C., L. W. Castellani, C. H. Warden, D. L. Puppione, and A. J. Lusis. 1993. Influence of mouse apolipoprotein A-II on plasma lipoproteins in transgenic mice. J. Biol. Chem. 268:20676-20682.

26. Warden, C. H., C. C. Hedrick, J. H. Qiao, L. W. Castellani, and A. J. Lusis. 1993. Atherosclerosis in transgenic mice overexpressing apolipoprotein A-II. Science (Wash. DC). 261:469-472.

27. Schultz, J. R., J. G. Verstuyft, E. L. Gong, A. V. Nichols, and E. M. Rubin. 1993. Protein composition determines the anti-atherogenic properties of HDL transgenic mice. Nature (Lond.). 365:762-764.

28. Barbaras, R., P. Puchois, J. C. Fruchart, and G. Ailhaud. 1987. Cholesterol efflux from cultured adipose cells is mediated by $\mathrm{Lp}(\mathrm{A}-\mathrm{I})$ particles but not by Lp(A-II) particles. Biochem. Biophys. Res. Commun. 142:63-69.

29. Vanloo, B., J. Taveirne, J. Baert, G. Lorent, L. Lins, J. M. Ruyschaert, and M. Rosseneu. 1992. LCAT activation properties of apo A-I CNBr fragments and conversion of discoidal complexes into spherical particles. Biochim. Biophys. Acta. 1128:258-266.

30. Puchois, P., A. Kandoussi, P. Fievet, J. L. Fourrier, M. Bertrand, E. Koren, and J. C. Fruchart. 1987. Apolipoprotein A-I containing lipoproteins in coronary artery disease. Atherosclerosis. 68:35-40.

31. Lussier-Cacan, S., J.-M. Bard, L. Boulet, A. C. Nestruck, A.-M. Grothé, J.-C. Fruchart, and J. Davignon. 1989. Lipoprotein composition changes induced by fenofibrate in dysbetalipoproteinemia type III. Atherosclerosis. 78:167-182.

32. Sirtori, C. R., and G. Franceschini. 1988. Effects of fibrates on serum lipids and atherosclerosis. Pharmacol. Ther. 37:167-191.

33. Manninen, V. 1983. Clinical results with gemfibrozil and background to the Helsinki Heart Study. Am. J. Cardiol. 52:35B-38B.

34. Lock, E. A., A. M. Mitchell, and C. R. Elcombe. 1989. Biochemical Mechanisms of induction of hepatic peroxisome proliferation. Ann. Rev. Pharmacol. Toxicol. 29:145-163.

35. Reddy, J. K., J. R. Warren, M. K. Reddy, and M. D. Lalwani. 1982. Hepatic and renal effects of peroxisomal proliferators: Biological implications. Ann. N Y Acad. Sci. 386:81-110.

36. van den Bosch, H., R. B. H. Schutgens, R. J. A. Wanders, and J. M. Tager. 1992. Biochemistry of peroxisomes. Ann. Rev. Biochem. 61:157-197.

37. Tolbert, N. E. 1981. Metabolic pathways in peroxisomes and glyoxysomes. Ann. Rev. Biochem. 50:133-157.

38. Reddy, J., D. Azarnoff, and C. Hignite. 1980. Hypolipidemic hepatic peroxisome proliferators form a novel class of chemical carcinogens. Nature (Lond.). 283:397-398.

39. Svoboda, D. J., D. L. Azarnoff, and C. E. Hignite. 1966. Response of hepatic microbodies to a hypolipidemic agent, ethylchlorophenoxyisobutyrate (CPIB). J. Cell Biol. 30:442-450.

40. Osumi, T., H. Ozasa, and T. Hashimoto. 1984. Molecular cloning of cDNA for rat acyl-CoA oxidase. J. Biol. Chem. 259:2031-2034.

41. Chatterjee, B., W. F. Demyan, N. D. Lalwani, J. K. Reddy, and A. K. Roy. 1983. Reversible alteration of hepatic messenger RNA species for peroxisomal and 
non-peroxisomal proteins induced by the hypolipidemic drug Wy 14,643. Biochem. J. 214:879-883.

42. Chatterjee, B., C. V. R. Murty, M. J. Olson, and A. K. Roy. 1987. Cloning and expression of the rat liver cDNA for peroxisomal enoyl-CoA hydratase, 3hydroxyacyl-CoA dehydrogenase in $\lambda$ GT11. Eur. J. Biochem. 166:273-278.

43. McQuaid, S., S. E. H. Russel, S. A. Withe, C. M. Pearson, C. R. Elcombe, and P. Humphries. 1987. Analysis of transcripts homologous to the acyl-CoA oxidase and enoyl-CoA hydratase/3-hydroxyacyl-CoA dehydrogenase induced in rat liver by methylclofenapate. Cancer Lett. 37:115-124.

44. Reddy, J. K., S. K. Goel, M. R. Nemali, J. J. Carrino, T. G. Laffler, M. K. Reddy, S. J. Sperbeck, T. Osumi, T. Hashimoto, N. D. Lalwani, and M. S. Rao. 1986. Transcriptional regulation of peroxisomal fatty acyl-CoA oxidase and enoylCoA hydratase/3-hydroxyacyl CoA dehydrogenase in rat liver by peroxisome proliferators. Proc. Natl. Acad. Sci. USA. 83:1747-1751.

45. Hijikata, M., N. Ishii, H. Kagamiyama, T. Osumi, and T. Hashimoto. 1987. Structural analysis of cDNA for rat peroxisomal 3-ketoacyl-CoA thiolase. J. Biol. Chem. 262:8151-8158.

46. Isseman, I., and S. Green. 1990. Activation of a member of the steroid hormone receptor superfamily by peroxisome proliferators. Nature (Lond.). 347:645-650.

47. Dreyer, C., G. Krey, H. Keller, F. Givel, G. Helftenbein, and W. Wahli. 1992. Control of the peroxisomal $\beta$-oxidation pathway by a novel family of nuclear hormone receptors. Cell. 68:879-887.

48. Gottlicher, M., E. Widmark, Q. Li, and J. A. Gustafsson. 1992. Fatty acids activate chimera of the clofibric acid-activated receptor and the glucocorticoid receptor. Proc. Natl. Acad. Sci. USA. 89:4653-4657.

49. Schmidt, A., N. Endo, S. J. Rutledge, R. Vogel, D. Shinar, and G. A Rodan. 1992. Identification of a new member of the steroid hormone receptor superfamily that is activated by a peroxisome proliferator and fatty acids. Mol. Endocrinol. 6:1634-1641.

50. Sher, T., H. F. Yi, W. McBride, and F. J. Gonzalez. 1993. cDNA cloning, chromosomal mapping, and functional characterization of the human peroxisome proliferator activated receptor. Biochemistry. 32:5598-5604.

51. Zhu, Y., K. Alvares, Q. Huang, M. S. Rao, and J. K. Reddy. 1993. Cloning of a new member of the peroxisome proliferator activated receptor gene family from mouse liver. J. Biol. Chem. 268:26817-26820.

52. Tontonoz, P., E. Hu, R. A. Graves, A. I. Budavari, and B. M. Spiegelman. 1994. mPPAR $\gamma 2$ : tissue-specific regulator of an adipocyte enhancer. Genes \& Dev. 8:1224-1234.

53. Aperlo, C., P. Pognonec, R. Saladin, J. Auwerx, and K. Boulukos. 1994. Isolation and characterization of the hamster peroxisomal proliferator activated receptor $\mathrm{hPPAR} \gamma$, a member of the nuclear hormone receptor superfamily. Gene. In press.

54. Kliewer, S. A., B. M. Forman, B. Blumberg, E. S. Ong, U. Borgmeyer, D. J. Mangelsdorf, K. Umesono, and R. M. Evans. 1994. Differential expression and activation of a family of murine peroxisome proliferator-activated receptors. Proc. Natl. Acad. Sci. USA. 91:7355-7359.

55. Osumi, T., J. K. Wen, and T. Hashimoto. 1991. Two cis-acting regulatory elements in the peroxisome proliferator-responsive element enhancer region of rat acyl-CoA Oxidase gene. Biochem. Biophys. Res. Commun. 175:866-871.

56. Tugwood, J. D., I. Isseman, R. G. Anderson, K. R. Bundell, W. L. McPheat, and S. Green. 1992. The mouse peroxisome proliferator activated receptor recognizes a response element in the 5 ' flanking sequence of the rat acyl CoA oxidase gene. EMBO (Eur. Mol. Biol. Organ.) J. 11:433-439.

57. Zhang, B., S. L. Marcus, F. G. Sajjadi, K. Alvares, J. K. Reddy, S. Subramani, R. A. Rachubinski, and J. P. Capone. 1992. Identification of a peroxisome proliferator-responsive element upstream of the gene encoding rat peroxisomal enoyl-CoA hydratase/3-hydroxyacyl-CoA dehydrogenase. Proc. Natl. Acad. Sci. USA. 89:7541-7545.

58. Marcus, S. L., K. S. Miyata, B. Zhang, S. Subramani, R. A. Rachubinski, and J. P. Capone. 1993. Diverse peroxisome proliferator-activated receptors bind to the peroxisome proliferator-responsive element of the rat hydratase/dehydrogenase and fatty acyl-CoA oxidase genes but differentially induce expression. Proc. Natl. Acad. Sci. USA. 90:5723-5727.

59. Alvarez, K., C. Fan, S. S. Daddras, A. V. Yelandi, R. A. Rachubinski, J. P. Capone, S. Subramani, P. M. Iannaccone, M. S. Rao, and J. K. Reddy. 1994. An upstream region of the enoyl-Coenzyme A hydratase 3-hydroxyacylCoenzyme A dehydrogenase gene directs luciferase expression in liver in response to peroxisome proliferators in transgenic mice. Cancer Res. 54:2303-2306.

60. Bardot, O., T. C. Aldridge, N. Latruffe, and S. Green. 1993. PPAR-RXR heterodimer activates a peroxisome proliferator response element upstream of the bifunctional enzyme gene. Biochem. Biophys. Res. Commun. 192:37-45.

61. Muerhoff, A. S., K. J. Griffin, and E. F. Johnson. 1992. The peroxisome proliferator activated receptor mediates the induction of CYP4A6, a cytochrome P450 fatty Acid $\varsigma$-hydroxylase, by clofibric acid. J. Biol. Chem. 267:1905119053.

62. Palmer, C. N. A., M.-H. Hsu, A. S. Muerhoff, K. J. Griffin, and E. F. Johnson. 1994. Interaction of the Peroxisome Proliferator-Activated Receptor $\alpha$ with the Retinoid X Receptor $\alpha$ unmasks a cryptic peroxisome proliferator response element that overlaps an ARP-1-binding site in the CYP4A6 promoter. $J$. Biol. Chem. 269:18083-18089.

63. Rodriguez, J. C., G. Gil-Gomez, F. G. Hegardt, and D. Haro. 1994. Peroxisome proliferator activated receptor mediates induction of the mitochondria 3-hydroxy-3-methylglutaryl-CoA Synthase gene by fatty acids. J. Biol. Chem. 269:18767-18772.

64. Gulick, T., S. Cresci, T. Caira, D. D. Moore, and D. P. Kelly. 1994 The peroxisome proliferator-activated receptor regulates mitochondrial fatty acid oxidative enzyme gene expression. Proc. Natl. Acad. Sci. USA. 91:11012-11016.

65. Vu-Dac, N., K. Schoonjans, B. Laine, J. C. Fruchart, J. Auwerx, and B. Staels. 1994. Negative regulation of the human apolipoprotein A-I promoter by fibrates can be attenuated by the interaction of the peroxisome proliferator-activated receptor with its response element. J. Biol. Chem. 269:31012-31018.

66. Staels, B., A. Van Tol, T. Andreu, and J. Auwerx. 1992. Fibrates influence the expression of genes involved in lipoprotein metabolism in a tissue selective manner. Arterioscler. Thromb. 12:286-294.

67. Simpson, H. S., C. M. Williamson, T. Olivecrona, S. Pringle, J. MacLean, A. R. Lorimer, F. Bonnefous, Y. Bogaievsky, C. J. Packard, and J. Shepherd 1990. Postprandial lipemia, fenofibrate and coronary artery disease. Atherosclerosis. 85:193-202.

68. Leroy, A., N. Vu-Dac, M. Koffigan, V. Clavey, and J.-C. Fruchart. 1988. Characterization of a monoclonal antibody that binds to apolipoprotein $\mathrm{E}$ and to lipoproteins of human plasma containing apo E. Applications to ELISA quantification of plasma apo E. J. Immunoassay. 9:309-334.

69. Luckow, B., and G. Schütz. 1987. CAT constructions with multiple unique restriction sites for the functional analysis of eukaryotic promoters and regulatory elements. Nucleic Acids Res. 15:5490.

70. Nakamaye, K. L., and F. Eckstein. 1986. Inhibition of restriction nuclease Ncil cleavage by phosphorothiolate groups and its application to oligonucleotidedirected mutagenesis. Nucleic Acids Res. 14:9679-9698.

71. Marsch, J. L., M. Erfle, and E. J. Wykes. 1984. The pIC plasmid and phage vectors with versatile cloning sites for recombinant selection by insertional inactivation. Gene. 32:481-485.

72. MacGregor, G. R., and C. T. Caskey, 1989. Construction of plasmids that express E. coli $\beta$-galactosidase in mammalian cells. Nucleic Acids Res. 17:2365.

73. Leid, M., P. Kastner, R. Lyons, H. Nakshatri, M. Saunders, T. Zacharewski, J. Y. Chen, A. Staub, J. M. Garnier, S. Mader, and P. Chambon. 1992 Purification , cloning, and RXR identity of the HeLa cell factor with which RAR or TR heterodimerizes to bind target sequences efficiently. Cell. 68:377-395.

74. Lee, A. P., A. Roque, D. J. Beck, and D. L. Kaminski. 1992. Isolation and culturing of hepatocytes from human liver. J. Tiss. Cult. Meth. 14:139-146.

75. Mosmann, T. 1983. Rapid colorimetric assay for cellular growth and survival: application to proliferation and cytotoxicity assays. J. Immunol. Methods. 65:55-63.

76. Chomczynski, P., and N. Sacchi. 1987. Single step method for RNA isolation by acid guanidinium-thiocyanate-phenol-chloroform extraction. Anal. Biochem. 162:156-159.

77. Tokunaga, K., Y. Nakaruma, K. Sakata, K. Fujimoro, M. Ohkubo, K. Sawada, and S. Sakiyama. 1987. Enhanced expression of a glyceraldehyde-3 phosphate dehydrogenase gene in human lung cancers. Cancer Res. 47:56165619.

78. Gorman, C. M., L. F. Moffat, and B. H. Howard. 1982. Recombinant genomes which express recombinant chloramphenicol acetyl transferase in mammalian cells. Mol. Cell Biol. 2:1044-1051.

79. Fried, M. G., and D. M. Crothers. 1983. CAP and RNA polymerase interactions with the lac promoter: binding stoichiometry and long range effects. Nucleic Acids Res. 11:141-158.

80. Keller, H., C. Dreyer, J. Medin, A. Mahfoudi, K. Ozato, and W. Wahli. 1993. Fatty acids and retinoids control lipid metabolism through activation of peroxisome proliferator-activated receptor-retinoid X receptor heterodimers. Proc. Natl. Acad. Sci. USA. 90:2160-2164.

81. Tora, L., J. White, C. Brou, D. Tasset, N. Webster, E. Scheer, and P. Chambon. 1989. The human estrogen receptor has two independent nonacidic transcriptional activation functions. Cell. 59:477-487.

82. Cardot, P., J. Chambaz, D. Kardassis, C. Cladaras, and V. I. Zannis. 1993. Factors participating in the liver-specific expression of the human apolipoprotein A-II gene and their significance for transcription. Biochemistry. 32:9080-9093.

83. Kardassis, D., V. I. Zannis, and C. Cladaras. 1990. Purification and characterization of nuclear factor BA1. A transcriptional activator of the human apo B gene. J. Biol. Chem. 265:21733-21740.

84. Auwerx, J. 1993. Regulation of gene expression by fatty acids and fibric acid derivatives: an integrative role for peroxisome proliferator activated receptors. Horm. Res. 38:269-277.

85. Staels, B., N. Vu-Dac, V. Kosykh, R. Saladin, J. C. Fruchart, J. Dallongeville, and J. Auwerx. 1995. Fibrates down-regulate apolipoprotein C-III expression independent of induction of peroxisomal Acyl Co-enzyme A Oxidase. J. Clin. Invest. 95:705-712. 